\title{
E-Learning Development Through The Animated Video Tutorial Media to Improve The Outcomes of Beauty Basic Learning
}

\author{
Erna Setyowati ${ }^{1}$, Syifaul Fida ${ }^{2}$ \\ \{ernasetyowaticy@gmail.com ${ }^{1}$,syifaulfida@gmail.com ${ }^{2}$ \} \\ Family Welfare Education, Faculty of Technical, Semarang State University
}

\begin{abstract}
The massage theory must be understood and practiced by the students of the Beauty Vocational School in class X, who have been less attractive by using the modules and drawings on paper sheets. The objectives of this research is to find out the feasibility of the video and learning outcomes after applying this tutorial video. The results showed that the animated video tutorial is very feasible (90.73) to improve the development for students in all of the $\mathrm{X}$ grade at vocational high schools. The learning outcomes that have increased from an average pre-test results to post test results, and the acquisition of understanding with an N-Gain test of 0.52 in moderate criteria. The conclusion are obtained that the improvement of e-learning through the animated video tutorial media is very feasible and can improve the results of learning outcomes.
\end{abstract}

Keywords: media, animation-video, massage, learning, results

\section{Introduction}

The basic of beauty is one of the subjects for the vocational high school students majoring beauty basic, where the students are faced with new material that has never been obtained before. Then the delivery of material will be more interesting with the selection of appropriate learning methods and media. The media is a means used to convey messages from a communicator to the communicant [8]. The use of media in the learning process is more efficient, effective and helps to absorb the subject matter deeper and complete the subject matter [2]. Regarding the media used when learning the beauty basic subjects, so far they still use printed modules and drawings. This media is often used in conveying material because it is easy to develop and search in various sources, but this print media has the disadvantage of not only showing dead images, no sound so it is very unattractive and seems outdated [1]. The media is a determinant of student learning success [9] The media is able to stimulate students' thoughts, concerns, feelings and abilities or skills so that they encourage learning activities that can improve student learning outcomes.

The learning media in the learning process serves to make learning more effective, accelerate the teaching and learning process and improve the quality of the teaching and learning process [4], which means changing the role of students more positively and productively and can help from other educational aspects such as personality formation, helping the learning difficulties and motivate learning. One of the learning media developed is video animation tutorial media with the help of Adobe Animate software that can be displayed via laptops and 
mobile phones. Animated videos can enrich students because they gain experience and competence [12]. It is necessary to design a video animation tutorial learning media to overcome the problems that exist in the school, so that learning becomes more effective [6]. By using video learning media, the teacher conveys lessons to students more easily for subject matter [11].

The animated video tutorials about the beauty basic subject can draw attention to the presence of sound and 24 massage movements in the real skin care steps, making it easier to describe the material and be able to explain something complicated to be more precise. The choice of video as a medium are able to combine between visuals and audio, can also be packaged in various forms. The benefits of video as a media are: 1) growing motivation, 2) the meaning of the message will be clearer so that it can be understood, (3) the audience will do more activities during the learning activities. The aims of this study were: 1) to determine the feasibility of the media 2) to determine the learning outcomes of the basic beauty subjects by using animated media tutorials for the Class X vocational high school students.

\section{Methods}

This research using the research and development (Research and Development) methods. This research is used to produce certain products, then test the effectiveness of these products. This research was conducted to develop and test the feasibility of instructional media animated video tutorials on beauty basic subjects with facial skin care materials for class $\mathrm{X}$ vocational high school students in semester I. Testing was conducted with one group pre-test post test, with the aim of obtaining information on whether the learning media was effective or not. no. Product design can be directly tested after being revised and validated by the experts [10].

The development model of animated video tutorial media for facial skin care that is used refers to the development model [5] which has been changed according to the conditions and needs. This study only took 7 stages out of 10 stages included: needs analysis, planning, development, small-scale trials, initial revisions, large-scale trials, and final products. The research development procedure can be explained as follows:

\subsection{Requirements Analysis}

At this stage, the needs analysis by observing and gathering information is carried out to study some of the existing literature in the form of books / printed images as initial material in compiling video animation tutorials.

\subsection{Planning}

The planning phase is carried out to arrange things related to research, starting from the video animation tutorial and everything that supports the research. Furthermore, formulating video content that is ajusted to the curriculum, syllabus, KI and KD, and RPP. This design formulation helps to clarify the direction of learning on the teaching material that will be developed through an animated video tutorial. This stage contains the contents, objectives and storyboard.

\subsection{Development}


The development phase is the stage where the researcher develops learning media in the form of video animation tutorials using Adobe Animate application. After developing, the product is assessed by 3 experts namely, 1 media expert, 1 educational technology expert, and 1 material expert. This is intended to evaluate the product that has been made, if found some deficiencies that must be corrected, then the animated video tutorial for facial skin care tutorial is revised, therefore it is ready to be tested.

\subsection{The Small Scale Test}

The small-scale test are conducted as initial trials after the video has been validated by the experts. A small scale trial was conducted involving 6 students as respondents.

\subsection{Initial Revision}

The media revision is done if in the process of learning media validation, one or more or all of the validator states that the media is invalid. The first stage of the product revision process is carried out in accordance with directions and instructions from the validator which states it is invalid. This process can be continued to the next stage if the learning media is declared valid by all expert validators.

\subsection{The Large-Scale Trials}

Conducting large-scale trials involving 30 students as samples to apply the product that has been made in the form of an animated video tutorial, with test collection techniques, the test is a pre-test before treatment and post-test after applying the video animation tutorial media in learning with the aim to retrieve data, and provide questionnaires for responses to students.

\subsection{Final Product}

The final product is produced from large-scale trials. At this stage the product can already be used as a learning media.

There are two research variables, namely the development of instructional video animation as the learning media which were previously in the form of teaching materials (facial care printed images), and the variable learning outcomes of the Class X students. Data analysis used was quantitative. Product data analysis includes media feasibility analysis by the experts, analysis of student responses, analysis of initial data with normality test, and final data analysis with N-gain test and hypothesis test. The sampling technique used was total sampling ie all (30 students of class X TKKR Vocational High School).

Data collection techniques used the observation methods to obtain data on the facial care learning activities. The test methods used to measure the knowledge possessed by students in the form of pre-test and post-test instruments. The questionnaire method in this study is divided into two namely:

1). Questionnaire for the expert lecturers consisting of the 3 expert lecturers to validate the eligibility of facial care tutorial animated videos (media experts, educational technology experts and the material experts)

2). Questionnaire for the responses given to students to obtain the response data on the animated video tutorial for facial treatment. 


\section{Results and Discussion}

\subsection{Media Development}

Observation and data collection that has been obtained by researchers take action by developing instructional videos animated tutorials using adobe animate software. The next step is testing through validation stage by 3 experts namely material experts, educational technology experts and media experts. Small group tests and initial revisions were also carried out, as well as large-scale trials accompanied by filling in questionnaires about the media that used by the students.

\subsection{Media Feasibility}

Product viability is determined from the results of the validator evaluation. Material experts, Educational technology experts and media experts aim to evaluate how feasible material and media developed and provide suggestions or revisions if deemed necessary. The following table summarizes the results of the average validation assessment of the experts:

Table 1. Average results of The Experts Validation Recapitulations

\begin{tabular}{llc}
\hline No. & Media Indicators Assesments & Percentage \\
\hline 1. & Material & $94,44 \%$ \\
2. & Education Technology & $90,97 \%$ \\
3. & Media & $86,80 \%$ \\
\hline & Average & $90,73 \%$
\end{tabular}

Based on the table above shows that the percentage obtained by the material experts is $94.44 \%$, from the educational technology experts $90.97 \%$, and $86.80 \%$ from the media experts. The average result of the three indicators above is $90.73 \%$ in the very feasible criteria, meaning that the media is feasible to be used as a learning media.

Table 2. The Learning Outcomes of Class X TKKR

\begin{tabular}{ccc}
\hline No & Pre-test & Post-test \\
\hline 1 & 67 & 79 \\
2 & 66 & 77 \\
3 & 71 & 82 \\
4 & 69 & 75 \\
5 & 66 & 77
\end{tabular}




\begin{tabular}{|c|c|c|}
\hline 6 & 71 & 82 \\
\hline 7 & 67 & 78 \\
\hline 8 & 65 & 83 \\
\hline 9 & 67 & 80 \\
\hline 10 & 69 & 77 \\
\hline 11 & 71 & 80 \\
\hline 12 & 73 & 79 \\
\hline 13 & 76 & 92 \\
\hline 14 & 70 & 90 \\
\hline 15 & 71 & 85 \\
\hline 16 & 70 & 96 \\
\hline 17 & 65 & 94 \\
\hline 18 & 71 & 90 \\
\hline 19 & 74 & 83 \\
\hline 20 & 68 & 89 \\
\hline 21 & 70 & 90 \\
\hline 22 & 76 & 98 \\
\hline 23 & 68 & 88 \\
\hline 24 & 67 & 93 \\
\hline 25 & 65 & 93 \\
\hline 26 & 68 & 77 \\
\hline 27 & 66 & 77 \\
\hline 28 & 65 & 88 \\
\hline 29 & 64 & 89 \\
\hline 30 & 72 & 93 \\
\hline Amounts & 2068 & 2554 \\
\hline Average & 68,9 & 85,2 \\
\hline Difference & \multicolumn{2}{|c|}{16,3} \\
\hline Lowest grade & 64 & 75 \\
\hline Highest grade & 76 & 98 \\
\hline
\end{tabular}

\subsection{The Difference in The Learning Outcomes Before and After using the Media}

The difference in learning outcomes before and after using the media can be known after conducting experiments in the sample class, namely the students of class $\mathrm{X}$ of Beauty Management at Taman Siswa Kudus, Vocational High School. From the data obtained, the average score of pre-test was 68.9 and post-test was 85.2. As a result students experience improved learning outcomes after using tutorial animation media. In addition to an increase in 
learning outcomes between pre-test and post-test, the data collection with a questionnaire was also conducted to determine student responses about the use of learning media that were developed.

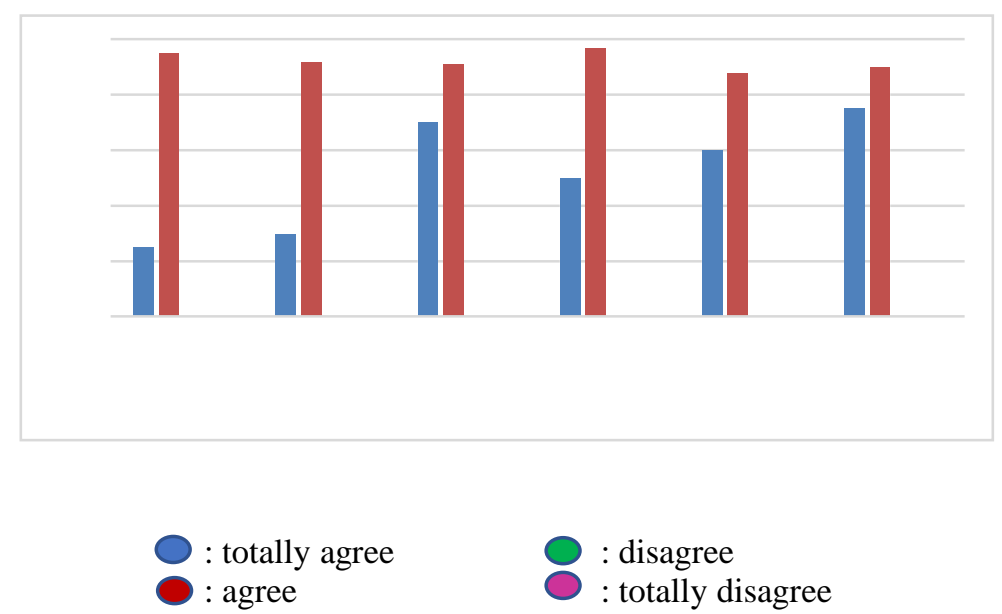

Fig. 1. Graph of the students responses

From the graph above shows that students are tend to agree and enthusiastic learning using animated video tutorial media which is very helpful in understanding facial treatment material. The average result of students' responses is $92.1 \%$ with very good criteria.

The results of the analysis with the N-Gain test to determine the increase in student holding from the pre-test and post-test results obtained 0.52 in the medium category.

\section{Discussion}

The development of basic beauty subject's learning media using Adobe CC Animate is carried out in several stages, including needs analysis, planning, development, small-scale trials, initial revisions, large-scale trials, final revisions. The material used in the animated video tutorial is facial care material on the facial massage.

Based on the indicators, the material delivered with instructional video animation tutorials provides effective understanding and can improve learning outcomes. The media selection criteria based on their accuracy with the learning objectives greatly affect student learning outcomes. Those findings are similar with the opinion[3] explained that material delivered using the media can affect the learning outcomes to be improved. The feasibility of the learning media used is very much needed as a tool to make it easier to convey the subject matter to students, so it is necessary to develop an interesting media. This is consistent with the opinion [7] which explains the benefits of learning media can lead to motivation, more interesting lessons, can directly interact actively in learning. 


\section{Conclussion}

1) The development of video animation tutorial learning media on the basic beauty subjects is carried out by researchers through 7 stages developed by Borg and Gall covering analysis, planning, development, small-scale trials, initial revisions, large-scale trials, and final products. The feasibility test are conducted by the material experts, the educational technology experts and the media experts stated that the instructional video animation tutorial media is very suitable to be used as a learning media.

2) The learning outcomes obtained by the pre-test and post-test have increased, analysis with $\mathrm{N}$-gain in the medium criteria. Suggestions from researchers for students are that the developed media can be used as a source of learning independently.

\section{References}

[1] Buchori, A.: Development Learning Model Of Characterducation Through E-comic In Elementary School. International Journal of Education and Research Vol.3, No.9 (2015)

[2] David, B.:Teaching with Media, a paper presented at Technology and Education Conference in Athens, Greece (1991)

[3] Dwijayanti, R., Marlena, N., dan Edwar, M.: Pengembangan Media Pembelajaran Multimedia Interaktif Berbasis Flash untuk Meningkatkan Hasil Belajar Mahasiswa. Jurnal Pendidikan Ekonomi \& Bisinis 6 (1): 51 (2018)

[4] Fahrurozi : The Development of Video Learning to Deliver a Basic Algorith Learning. Indonesian Journal of Informatics Education Vol.1 No.2 (2017)

[5] Haryanti, S.: Research and Development (R\&D) Sebagai Salah Satu Model Penelitian dalam Bidang Pendidikan. Majalah Ilmiah Dinamika Vol.37 No.1 (2012)

[6] Kusuma : Pengembangan Media Pembelajaran Video Tutorial Berbasis Website Untuk Meningkatkan Hasil Belajar Peserta Didik Mata Pelajaran Pemasaran Online SMK Negeri Kabupaten Sukoharjo. Jurnal Pendidikan Bisnis dan Ekonomi Vol.4 No.1 (2018)

[7] Nurseto, T.: Membuat Media Pembelajaran Yang Menarik. Jurnal Ekonomi \& Pendidikan 08(1): 22 (2011)

[8] Purwono : Penggunaan Media Audi-Visual Pada Mata Pelajaran Ilmu Pengetahuan Alam di Sekolah Menegah Pertama Negeri 1 Pacitan. Jurnal Teknologi Pendidikan dan Pembelajaran Vol.2 No.2 (2014)

[9] Sari : The Development of Writing Learing Media In Audio Visual Based on Explanatory Text at The Students of Class XI MAN 2 Model Medan Indonesia. International Journal of Education Learning and Development Vol.5 No.10 (2017)

[10] Sugiyono : Metode Penelitian Kombinasi. Bandung: Alfabeta (2015)

[11] Tasmalina : Pengaruh Media Video Pembelajaran Terhadap Hasil Belajar Siswa Pada Sub Materi Spermatophyte Di SMA Swasta Nurul Amaliyah Tanjung Morawa Tahun Pembelajaran 2015/2016. Jurnal Biology Education Science and Technology Vol.1 No.01 (2018) 
[12] Yusuf : Developing of Instructional Media Based Animation Videoon Enzyme and Metabolism Material in Senior High School. Indonesian Journal Of Biology Education Vol.3No.3 (2017) 